\title{
Small Group Learning: Solusi Belajar pada Masa Pandemi
}

\author{
Farid Helmi Setyawan \\ Pendidikan Bahasa Inggris Universitas Borneo Tarakan \\ faridhelmi@borneo.ac.id
}

\begin{abstract}
Abstrak
Pembelajaran melalui daring pada pandemi Covid-19 memiliki dampak negatif, salah satunya ialah penurunan kualitas pendidikan (learning loss). Salah satu upaya untuk menanggulangi learning loss dapat dilakukan dengan membuat kelompok belajar kecil di setiap daerah pada level RT dengan konsep Kampung Belajar. Penelitian ini bertujuan untuk mengetahui efektifitas penerapan Small Group Learning sebagai upaya mengatasi learning loss serta mengetahui perspektif peserta didik dan orangtua terhadap penerapan metode Small Group Learning ini. Penelitian ini merupakan deskriptif kualitatif dengan subjek penelitian adalah 100 peserta didik tingkat SMP. Teknik pengumpulan data menggunakan observasi, wawancara dan dokumentasi. Teknik analisis data menggunakan reduksi data atau penyederhanaan data, penyajian data, Penarikan Kesimpulan atau verifikasi. Pemeriksaan keabsahan data menggunakan triangulasi teknik dan triangulasi sumber. Pemeriksaan keabsahan data menggunakan triangulasi teknik dengan menggunakan tiga teknik pengumpulan data yaitu observasi, wawancara dan dokumentasi. Pemeriksaan keabsahan data menggunakan triangulasi sumber yaitu dengan menggunakan sumber data yang berasal dari guru. Berdasarkan hasil penelitian dapat disimpulkan bahwa penerapan metode Small Group Learning dengan konsep Kampung Belajar dinyatakan efektif dan mampu memberikan solusi terhadap learning loss yang dihadapi peserta didik serta mampu meningkatkan motivasi belajar peserta didik.
\end{abstract}

Kata Kunci: learning loss, small group learning, solusi belajar masa pandemi

\section{PENDAHULUAN}

Pandemi COVID-19 yang membuat pilu ini dirasakan dampaknya oleh seluruh penduduk dunia. Semua segmen kehidupan menjadi terganggu, begitu juga dunia pendidikan. Pada akhirnya, banyak negara memutuskan untuk menutup sementara kegiatan pada sekolah, perguruan tinggi maupun pendidikan formal lainnya, termasuk negara Indonesia, untuk mencegah penyebaran wabah virus. Krisis yang datang tiba-tiba memaksa pemerintah di seluruh dunia termasuk Indonesia untuk segera mengambil keputusan dengan menutup kegiatan pertemuan tatap muka di sekolah untuk menghindari mewabahnya covid 19 dan mengurangi kontak fisik orang-orang secara masif dan untuk menyelamatkan hidup atau mengambil risiko dengan tetap harus mengadakan pertemuan tatap muka di sekolah dalam rangka survive demi menjaga keberlangsungan ekonomi.

Terdapat dua dampak yang disebabkan oleh pandemi Covid-19 bagi pendidikan menurut (Syah, 2020), pertama adalah dampak jangka pendek yang dialami dan dirasakan oleh banyak keluarga di Indonesia baik di kota maupun di desa. Banyak keluarga di Indonesia yang kurang mengenal dan kurang siap untuk mengadakan pembelajaran di rumah. Kegiatan bersekolah atau pembelajaran di rumah adalah kejutan besar bagi keluarga khususnya untuk orang tua yang biasanya sibuk atau banyak kegiatan dengan pekerjaan di luar rumah. Begitu juga dengan masalah psikologis peserta didik yang sudah terbiasa belajar secara tatap muka langsung dengan guru-guru di sekolah yang pada akhirnya dengan terpaksa melaksanaan pembelajaran jarak jauh (pembelajaran daring/online). Pada 
pelaksanaannya, proses pembelajaran daring ini adalah pembelajaran yang belum pernah terukur dan teruji dikarenakan kondisi pandemi ini belum pernah terjadi sebelumnya. Pembelajaran daring yang ada pada sekolah-sekolah di desa mengakibatkan desa yang memiliki penduduk usia sekolah sangat padat menjadi kebingungan dikarenakan fasilitas teknologi informasi yang sangat terbatas.

Kedua adalah dampak jangka panjang. Dampak pandemi covid 19 pada pendidikan dilihat dari sisi jangka panjang adalah pada aspek keadilan dan peningkatan ketidaksetaraan antar kelompok masyarakat dan antardaerah di Indonesia. Penilaian terhadap kemampuan peserta didikpun juga banyak yang mengalami kendala karena mengalami hambatan. Selain itu Pembelajaran melalui daring memiliki dampak negatif, salah satunya ialah penurunan kualitas pendidikan. Penurunan tersebut disebut dengan loss learning (Safira \& Ifadah, 2021). Learning loss bisa dipastikan akan terjadi pada peserta didik karena dampak pembelajaran online yang kurang optimal.

Menteri Pendidikan dan Kebudayaan (Mendikbud), Nadim Makariem, (Jakarta, CNN Indonesia, Januari 2021) mendorong pemerintah daerah untuk membuka pembelajaran tatap muka di sekolah. Bapak Nadiem Makariem mengkhawatirkan akan terjadinya learning loss pada peserta didik. Learning loss adalah kondisi kehilangan kesempatan untuk menambah ilmu yang dikarenakan adanya proses belajar mengajar yang tertunda pada sebuah generasi tertentu (Pratiwi, 2021). Learning loss juga merupakan kondisi dan suasana hilangnya kesempatan dan waktu belajar yang optimal sebagai dampak atau akibat dari proses pelaksanaan pembelajaran yang tidak seperti biasanya. Learning loss apabila tidak segera diatasi akan menjadi kondisi yang berbahaya bagi kehidupan nasional dan dunia yang berkaitan dengan kualitas pendidikan secara global (Komalawati, 2020).

Menurut Nadiem kondisi pandemic saaat ini merupakan kondisi yang susah untuk menghindari adanya learning loss. Maka dari itu, Kemendikbud mendorong penerapan pembelajaran jarak jauh (PJJ) untuk para peserta didik yang harus belajar di rumah, akan tetapi pada kenyataan di lapangan banyak hal yang menjadi hambatan dalam pelaksanaan PJJ. Berdasarkan hasil observasi dan wawancara dengan beberapa peserta didik SMP, banyak hal yang dihadapi oleh peserta didik selama pelaksanaan PJJ, mulai dari koneksi internet yang tidak mendukung, waktu belajar yang kurang efektif, serta model pembelajaran yang disampaikan oleh guru yang kurang menarik serta faktor kesenjangan yang terjadi pada peserta didik antara peserta didik dengan latar belakang ekonomi mampu dan tidak mampu. Hal tersebut menimbulkan menurunnya motivasi belajar peserta didik sehingga kemampuan akademik peserta didik mengalami penurunan (Pratiwi, 2021). Hambatanhambatan tersebut jika terus diabaikan, maka tidak menutup kemungkinan terjadinya learning loss pada peserta didik.

Ada beberapa langkah yang dapat menjadi alternatif solusi untuk mengatasi masalah learning loss. Langkah awal untuk menyelesaikan permasalahan learning loss adalah melakukan identifikasi hambatan atau kesulitan belajar peserta didik, mengidentifikasi penyebab permasalahan, dan mencari alternatif solusi untuk menyelesaikan hambatan atau kesulitan belajar peserta didik tersebut. Proses identifikasi hambatan dan kesulitan belajar peserta didik dapat dilakukan melalui asesmen atau penilaian pembelajaran yang bersifat diagnostik. Penilaian diagnostik dilaksanakan untuk mendiagnosis hambatan atau kesulitan belajar peserta didik dan mengidentifikasi penyebabnya untuk dirumuskan tindak lanjut 
perbaikan. Langkah selanjutnya adalah memberikan alternatif metode belajar pada peserta didik untuk menunjang pelaksanaan kegiatan PJJ yang sudah berlangsung selama pandemi.

Beberapa metode pembelajaran banyak ditawarkan selama masa pandemic berlangsung seperti:, Daring Method, Project Based Learning, Luring Method, Integrated Curriculum, Home Visit Method, , Blended Learning dan salah satu lagi Small Group Learning (Admin Sevima, 2020). Dari beberapa metode belajar tersebut memiliki keunggulan masing-masing dan lebih cocok diterapkan pada jenjang pendidikan tertentu. Melihat beberapa metode belajar tersebut, peneliti lebih cenderung memilih menerapkan metode belajar Small Group Learning karene dirasa lebih bias mengakomodir dari beberapa metode belajar lainnya.

Small Group Learning atau juga biasa disebut bimbingan kelompok kecil, adalah metode pengajaran tambahan, disampaikan secara konsisten untuk jangka waktu yang telah ditentukan, untuk mendukung pembelajaran peserta didik dalam skala kecil (sekitar 2-5 peserta didik). Hal ini dimaksudkan untuk memperkuat instruksi kelas, lebih disukai di luar kelas yang dijadwalkan secara teratur atau dalam bentuk pilihan (Victoria State Government, 2020). "Small group learning is a highly effective remedial learning and teaching strategy for students experiencing educational disadvantage, especially those who have faced particular barriers during remote and flexible learning that they might not have faced while at school. It provides an environment in which differentiated and targeted interventions reinforce the classroom teacher's instruction, through tutors providing further scaffolding tailored to each student's point of learning need" (Victoria State Government, 2020).

\section{METODE}

Penelitian ini menggunakan penelitian deskriptif kualitatif dimana untuk memaparkan hasil observasi kegiatan pembelajaran menggunakan metode small group learning. Subyek penelitian adalah 50 orang peserta didik SMP yang dibagi menjadi 10 kelompok kecil untuk penerapan metode small group learning. Teknik pengumpulan data menggunakan teknik observasi atau pengamatan, wawancara, dan dokumentasi. Teknik analisis data menggunakan reduksi data, penyajian data, penarikan kesimpulan atau verifikasi. Teknik pemeriksaan keabsahan data menggunakan teknik triangulasi dan triangulasi sumber. Pemeriksaan keabsahan data menggunakan teknik triangulasi dengan menggunakan tiga teknik pengumpulan data yaitu observasi atau pengamatan, wawancara, dan dokumentasi. Pemeriksaan keabsahan data menggunakan teknik triangulasi sumber yaitu dengan menggunakan sumber data yang berasal dari guru.

\section{HASIL DAN PEMBAHASAN}

Dari penerapan metode small group learning diperoleh bebrapa hal baik kelebihan dan kekurangan. Kelebihan dari penerapan metode ini adalah pembelajaran hanya terfokus pada satu kelompok kecil peserta didik sehinga pembelajaran terlaksana dengan efektif. Dengan kelompok kecil, diskusi pembelajaran dan pembahasan permasalahan dalam pembelajaran dapat berjalan dengan maksimal. Komunikasi antar peserta didik terjalin dengan baik, begitu pula interaksi antara pendidik dengan peserta didik juga terjalin dengan sangat baik. Motivasi belajar peserta didik untuk mengikuti pembelajaran juga meningkat dikarenakan dengan metode small group learning, peserta didik mampu menyampaikan aspirasi mereka tanpa ada rasa canggung. Small group learning memberikan peluang kepada peserta didik untuk menanyakan hal yang mereka tidak 
pahami sehingga mereka akan lebih menguasai kompetensi belajar yang akan dicapai. Hal ini sejalan dengan penelitian dari Kamaluddin $\mathrm{H}$. Ahmad dan Siti Nurma 2020 yang menyebutkan bahwa pembelajaran small group di MTs Al-Raisiyah Mataram bisa meningkatkan motivasi belajar peserta didik dalam pembelajaran PPKn,

Pembelajaran small group memiliki dampak positif karena pada saat pembelajaran terjadi kegiatan diskusi peserta didik sehingga peserta didik nampak lebih aktif (Ahmad \& Nurma, 2020). Penerapan small group learning juga memberikan beberapa keuntungan yaitu: 1) memungkinkan peserta didik untuk menemukan dan terlibat dengan berbagai perspektif, ide, dan latar belakang, 2) memberikan peserta didik kesempatan untuk lebih terlibat aktif, 3) membantu peserta didik untuk mengklarifikasi sikap dan gagasan mereka tentang mata pelajaran penting, saat mereka menguji ide dan sikap mereka sendiri terhadap orang lain, 4) membantu peserta didik mengembangkan rasa ketelitian akademis dan kemauan untuk berbagi ide, 5) memberikan peluang bagi peserta didik untuk menerima lebih banyak masukan langsung pada pembelajaran mereka, 6) mendorong peserta didik untuk belajar mandiri dan mandiri, 7) memberikan peluang bagi peserta didik untuk lebih mudah mendapatkan kesadaran terhadap reaksi emosi mereka, 8) memberikan peluang bagi peserta didik untuk belajar dan mengembangkan perilaku kooperatif termasuk pemikiran kritis dan proses memecahkan masalah kelompok, 9) lebih mudah menjalin hubungan antara guru dan peserta didik, dan 10) memberikan lebih banyak kesempatan untuk mengembangkan keterampilan dalam komunikasi (mendengarkan, merespons, berinteraksi) dan hubungan interpersonal (Toohey, 2004).
Hubungan yang kuat juga merupakan elemen penting dari small group learning. Guru harus bekerja sama dengan peserta didik, serta orang tua dan wali, untuk menyelaraskan dengan pilihan gaya belajar peserta didik, tujuan yang teridentifikasi, dan kebutuhan peserta didik secara keseluruhan. Proses ini harus tetap koheren dengan tujuan kurikulum yang lebih luas, dan mendukung kemajuan peserta didik terhadap kurikulum yang ditentukan melalui observasi guru dan analisis data peserta didik (Victoria State Government, 2020). Melalui metode small group learning ini interaksi guru dengan peserta didik dapat berlangsung dengan baik karena jumlah peserta didik dalam satu kelompok hanya terdiri dari 5 orang sehingga proses komunikasi dapat terjalin dengan baik. Berbeda dengan komunikasi ketika pembelajaran daring dengan jumlah peserta didik yang banyak. Informasi dari guru dapat dengan mudah diterima oleh peserta didik dikarenakan jumlah peserta didik dalam satu kelompok tergolong kecil. Kontrol terhadap perkembangan akademik peserta didik selama pelaksanaan metode juga sangat mudah dibandingkan dengan pelaksanaan pada kelas besar. Hal tersebut juga memberikan kontribusi positif pada perkembangan belajar peserta didik serta menumbuhkan motivasi belajar bagi peserta didik.

Small group learning juga bias diterapkan secara daring dengan membentuk kelompok kecil dengan menggunakan fitur breakout room pada aplikasi zoom. Tetapi penerapan tersebut banyak mengalami kendala. Dari hasil percobaan yang dilakukan oleh peneliti, penerapan small group learning secara daring banyak terdapat kekurangan. Kekurangan yang ditemukan dalam pelaksanaan small group learning adalah kendala jaringan internet yang kurang stabil, beberapa peserta didik mengeluhkan koneksi internet yang buruk sehingga pembelajaran mengalami gangguan. 
Selain itu karena terdapat beberapa kelompok, pembelajaran memerlukan waktu yang cukup banyak dan yang paling menyita banyak waktu adalah pengulangan pembelajaran jadi dengan kata lain efektifitas waktu kurang. Hal ini merupakan kendala yang juga disampaikan oleh (Hutauruk \& Sidabutar, 2020) dalam penelitiannya dengan judul Kendala Pembelajaran Daring Selama Masa Pandemi di Kalangan Mahapeserta didik Pendidikan Matematika: Kajian Kualiatatif Deskriptif. Hal yang disampaikan pada penelitian tersebut adalah kendala jaringan internet serta waktu yang banyak tersita untuk kegiatan pembelajaran daring dengan sistem kelompok kecil. Sangat dirasakan tidak efektif dan efisien waktu dalam pelaksanaan metode small group learning ini.

Peneliti mengalami masa dimana waktu yang digunakan untuk memberikan materi dirasa cukup melelahkan karena harus mengulang penyampaian materi sebanyak sepuluh kali pada jenjang kelas yang sama. Meski banyak memakan waktu, hal positif yang didapatkan adalah hasil capaian belajar peserta didik dapat dikatakan berhasil dan memenuhi ketercapaian kompetensi yang diharapkan. Selain itu, interaksi dalam pembelajaran dantara guru dengan peserta didik dapat terjalin dengan intens dan guru dapat memahami kebutuhan peserta didik dalam belajar. Persepsi orangtua peserta didik terhadap pelaksanaan metode ini juga dirasakan sangat positif. Dari hasil wawancara dengan orangtua peserta didik, mereka menyampaikan bahwa kegiatan belajar dengan system metode small group learning ini menjadi solusi belajar yang efektif ditengah pandemic seperti ini. Orangtua peserta didik juga menyampaikan bahwa dengan metode ini anak mereka menjadi termotivasi dalam belajar dikarenakan kegiatan belajar dirasakan seperti layaknya tatap muka. Peserta didik merasa mendapat pelayanan yang maksimal akan kebutuhan belajar mereka. Hal ini mematahkan persepsi negative orangtua jika belajar online hanya diberi tugas dan tugas tanpa adanya penjelasan materi dan pendampingan dari guru.

\section{PENUTUP}

\section{Simpulan}

Kesimpulan pada penelitian ini adalah pentingnya menciptakan interaksi belajar antara pendidik dengan peserta didik agar tidak terjadi learning loss yang mana proses pembelajaran kehilangan makna pentingnya. Dengan menerapkan small online discussion dan dipadukan dengan beberapa metode cooperative learning dengan memusatkan peserta didik sebagai pusat pembelajaran, akan lebih menciptakan interaksi belajar yang baik. Small online discussion dipilih untuk menanggulangi kebosanan peserta didik dalam pembelajaran online yang hasilnya dapat dilihat bahwa metode ini mampu menciptakan interaksi belajar yang baik dan proses pembelajaran berjalan dengan baik. Dengan penerapan metode ini juga mematahkan persepsi negative orangtua terhadap pembelajaran online yang selama ini dilaksanakan.

\section{Saran}

Saran dari peneliti untuk peneliti selanjutnya adalah, perlunya memperhatikan kombinasi model pembelajaran yang akan digunakan untuk mendukung small group learning sehingga dalam pembelajaran terjadi interaksi dan komunikasi antara peserta didik dengan guru.

\section{DAFTAR PUSTAKA}

Admin Sevima. (2020). 6 Metode Pembelajaran Paling Efektif di Masa Pandemi Menurut Para Pakar. Sevima.Com, July, 1-8. https://sevima.com/6-metodepembelajaran-paling-efektif-di-masapandemi-menurut-para-pakar/

Ahmad, K. H., \& Nurma, S. (2020). Penerapan Metode Small Group Discussion Terhadap 
Motivasi Belajar Peserta didik. 8(1), 3035.

Hutauruk, A., \& Sidabutar, R. (2020). Kendala Pembelajaran Daring Selama Masa Pandemi di Kalangan Mahapeserta didik Pendidikan Matematika: Kajian Kualiatatif Deskriptif. SEPREN: Journal of Mathematics Education and Applied, 02(01), 45-51.

Komalawati, R. (2020). Manajemen Pelaksanaan Tes Diagnostik Awal Untuk Mengidentifikasi Learning Loss. Jurnal EDUPENA, 01(2), 135-148.

Pratiwi, W. D. (2021). Dinamika Learning Loss: Guru Dan Orang Tua. Jurnal Edukasi Nonformal, 2(1), 147-153.

Ru, O. H. P. (2021). Opini PTM sebagai Upaya Mencegah Ancaman Learning Loss. 2-5.

Safira, A. R., \& Ifadah, A. S. (2021). The Readiness Of Limited Face To Face Learning In The New Normal Era. JCES (Journal of Character Education Society), 4(3), 643-651.

Syah, R. H. (2020). Dampak Covid-19 pada Pendidikan di Indonesia: Sekolah, Keterampilan, dan Proses Pembelajaran. SALAM: Jurnal Sosial Dan Budaya Syar-I, 7(5).

https://doi.org/10.15408/sjsbs.v7i5.15314

Toohey, S. (2004). Small Group Teaching - key theories and methods. UNSW Faculty of Medicine, http://www.nevadaadulteducation.org/nvrb /SmallGroupTeaching.pdf

Victoria State Government. (2020). Out-ofClass Small Group Learning: Advice for Schools Getting Started. June, 1-11. 